\title{
PENERAPAN STRATEGI PRACTICE REHEARSAL PAIRS PADA MATA KULIAH SENI TARI DAN DRAMA DI UPGRIS
}

\author{
Prasena Arisyanto ${ }^{1}$, Mei Fita Asri Untari ${ }^{2}$, dan Riris Setyo Sundari ${ }^{3}$ \\ ${ }^{1,2,3}$ Program Studi Pendidikan Guru Sekolah Dasar, FIP, UPGRIS \\ Email: prasenaarisvanto@upgris.ac.id
}

\begin{tabular}{|c|c|}
\hline Info Artikel & Abstract \\
\hline $\begin{array}{l}\text { Sejarah Artikel: } \\
\text { Diserahkan } 25 \text { September } 2018 \\
\text { Direvisi } 15 \text { November } 2019 \\
\text { Disetujui } 18 \text { November } 2019\end{array}$ & $\begin{array}{l}\text { This study aims to measure student learning outcomes and analyze the character education } \\
\text { process in dance and drama courses at UPGRIS PGSD Study Program through practice } \\
\text { rehearsal pairs. } \\
\text { The research method used is a quantitative-qualitative mixed method. The target of this } \\
\text { research is focused on dance and drama lectures in the even semester 2017/2018. The } \\
\text { research was conducted at the Elementary School Teacher Education Study Program, } \\
\text { Faculty of Education, University of PGRI Semarang. There are } 4 \text { data collection } \\
\text { techniques used in this study, namely observation, interview, questionnaire and document } \\
\text { study. The data validity technique used is triangulation technique and source triangulation. } \\
\text { Data analysis techniques use the Gain index formula for quantitative analysis, and analysis } \\
\text { of learning concepts and character education for qualitative analysis. } \\
\text { The results showed that the application of rehearsal pairs practice strategies can improve } \\
\text { student learning outcomes in the appreciation of dance material by bringing Dolalak } \\
\text { dance. Measurement of learning outcomes is done by Gain index and get the result of } g= \\
1,02 \text { or g> } 0,7 \text { which is included in the high category. Increasing student learning } \\
\text { outcomes are influenced by learning materials, learning methods, and student factors } \\
\text { themselves. Students become more enthusiastic to practice outside of lecture hours because } \\
\text { there are friends who become their study partners. The adoption of pairs of rehearsal } \\
\text { practice strategies can also strengthen character education for students, including caring, } \\
\text { cooperation, responsibility, and democratic character, which is strengthened through face- } \\
\text { to-face lecture processes and independent training tasks. }\end{array}$ \\
\hline
\end{tabular}

\begin{abstract}
Abstrak
Penelitian ini bertujuan untuk mengukur hasil belajar mahasiswa dan menganalisis proses pendidikan karakter dalam mata kuliah tari dan drama di Prodi PGSD UPGRIS melalui strategi practice rehearsal pairs.

Metode penelitian yang digunakan adalah metode campuran kuantitatif-kualitatif. Sasaran penelitian ini terfokus pada perkuliahan seni tari dan drama pada semester genap 2017/2018. Penelitian dilaksanakan pada Program Studi Pendidikan Guru Sekolah Dasar, Fakultas Ilmu Pendidikan, Universitas PGRI Semarang. Teknik pengumpulan data yang digunakan dalam penelitian ini ada 4 yaitu observasi, wawancara, angket dan studi dokumen. Teknik keabsahan data yang digunakan adalah triangulasi teknik dan triangulasi sumber. Teknik analisis data menggunakan rumus indeks Gain untuk analisis kuantitatif, dan analisis konsep pembelajaran dan pendidikan karakter untuk analisis kualitatif.

Hasil penelitian menunjukan bahwa penerapan strategi practice rehearsal pairs dapat meningkatkan hasil belajar mahasiswa pada materi apresiasi seni tari dengan membawakan tari Dolalak. Pengukuran hasil belajar dilakukan dengan indeks Gain dan mendapatkan hasil $\mathrm{g}=1,02$ atau $\mathrm{g}>0,7$ yang termasuk dalam kategori tinggi. Peningkatan hasil belajar mahasiswa dipengaruhi oleh materi pembelajaran, metode pembelajaran, dan faktor mahasiswa itu sendiri. Mahasiswa menjadi lebih semangat untuk berlatih diluar jam perkuliahan dikarenakan ada teman yang menjadi pasangan belajarnya. Penerapan strategi practice rehearsal pairs juga dapat memperkuat pendidikan karakter pada mahasiswa diantaranya karakter peduli, kerjasama, tanggung jawab, dan demokratis, yang dikuatkan melalui proses perkuliahan tatap muka dan tugas latihan mandiri.
\end{abstract}

(C) 2019 Universitas Muria Kudus 


\section{PENDAHULUAN}

Metode meniru dalam pembelajaran seni tari dan drama perlu ditunjang atau didukung dengan metode lain agar pembelajaran menjadi lebih baik dan bermanfaat. Salah satu metode atau strategi pembelajaran yang dapat digunakan yaitu strategi practice rehearsal pairs. Strategi practice rehearsal pairs dapat diterapkan pada materi tari berpasangan maupun kelompok, dikarenakan strategi practice rehearsal pairs menuntut peserta didik untuk dapat berkomunikasi dengan teman yang menjadi pasangannya.

Strategi practice rehearsal pairs juga menuntut keaktifan peserta didik dalam proses pembelajaran. Melalui strategi pembelajaran aktif diharapkan kemampuan peserta didik dapat lebih meningkat. Kemampuan yang diharapkan meningkat bukan hanya kemampuan kognitif atau kemampuan akademik saja, tetapi juga kemampuan afektif dan kemampuan psikomotorik dengan penerapan strategi practice rehearsal pairs.

Pelaksanaan perkuliahan tari dan drama sebagai proses pendidikan seni pada program studi Pendidikan Guru Sekolah Dasar UPGRIS mempunyai dua fungsi dilihat dari orientasi kebutuhan mahasiswa dan orientasi kebutuhan institusi pendidikan (Syafii, 2014). Fungsi dalam orientasi kebutuhan mahasiswa mempunyai tujuan sebagai wahana pendidikan nilai, pengungkapan ekspresi, dan mengembangkan potensi kreatif mahasiswa melalui media seni, bukan untuk mendidik mahasiswa menjadi seniman dibidang seni tertentu. Fungsi dalam orientasi institusi pendidikan adalah universitas mampu meningkatkan kualitas lulusannya karena mahasiswa diharapkan dapat memanfaatkan seni sebagai media pendidikan ketika telah masuk ke sekolah sebagai guru.

Berdasarkan penelitian Arisyanto et al (2018), dan Sustiawati et al (2017), disimpulkan bahwa pendidikan karakter di sekolah dasar dapat dilakukan melalui pembelajaran seni tari. Berdasarkan penelitian tersebut, peneliti berasumsi bahwa pendidikan karakter di perguruan tinggi juga dapat dilakukan melalui perkuliahan seni tari dan drama. Penelitian mengenai pendidikan seni di Universitas antara lain oleh Desfiarni (2009) dan Tandi (2012). Namun dua penelitian tersebut belum membahas pengembangan proses perkuliahan yang berkaitan dengan pengembangan karakter mahasiswa. Penelitian lebih terfokus pada pengembangan materi dan model perkuliahan seni tari.

Penelitian sebelumnya mengenai strategi practice rehearsal pairs dilakukan oleh Noviana (2013), Pratiwi (2016), dan Nurrika (2016), namun penelitian yang dilakukan terfokus pada pembelajaran di SD dan SMP. Penelitian mengenai strategi practice rehearsal pairs pada mata kuliah seni tari dan drama di program studi PGSD melalui belum pernah dilakukan sebelumnya, oleh karena itu pada penelitian ini difokuskan pada penerapan strategi dan pengembangan karakter mahasiswa prodi PGSD UPGRIS melalui strategi practice rehearsal pairs.

Program studi PGSD UPGRIS dipilih karena para mahasiswa disiapkan utamanya untuk menjadi guru di tingkat sekolah dasar. Pendidikan di sekolah dasar membutuhkan metode yang menarik dan unik, dan salah satunya seni dapat menjadi pilihan untuk menjadi media pendidikan, oleh karena itu mahasiswa sebagai calon guru juga harus dipersiapkan secara teknis agar dapat memanfaatkan seni sebagai media pembelajaran.

Pendidikan seni juga dimanfaatkan sebagai pendidikan karakter agar para calon guru juga mempunyai karakter yang baik sehingga dapat menjadi teladan bagi siswa-siswanya. Penelitian ini perlu dilakukan untuk menganalisis penerapan strategi practice rehearsal pairs untuk mengembangkan kompetensi mahasiswa PGSD dalam pembelajaran seni tari, dan sebagai media pengembangan karakter mahasiswa sebagai calon guru. Hasil penelitian diharapkan dapat menjadi sumber informasi untuk melakukan penelitian pengembangan di tahun selanjutnya maupun menjadi referensi bagi penelitian sejenis.

\section{METODE PENELITIAN}

Metode penelitian yang digunakan yakni metode campuran kuantitatif-kualitatif (Sugiyono, 2011). Sasaran penelitian ini terfokus pada perkuliahan seni tari dan drama pada semester genap 2017/2018. Penelitian dilaksanakan pada Program Studi Pendidikan Guru Sekolah Dasar, Fakultas Ilmu Pendidikan, Universitas PGRI Semarang. Teknik pengumpulan data yang digunakan dalam penelitian ini ada 4 yaitu observasi, wawancara, angket dan studi dokumen. Teknik keabsahan data yang digunakan adalah triangulasi teknik dan triangulasi sumber. 
Prasena Arisyanto, Mei Fita Asri Untari, dan Riris Setyo Sundari

PENERAPAN STRATEGI PRACTICE REHEARSAL PAIRS PADA KULIAH SENI TARI DAN DRAMA ... REFLEKSI EDUKATIKA : Jurnal Ilmiah Kependidikan 10 (1) Desember 2019. Hlm. 1-9

$$
\begin{gathered}
\text { Indeks Gain } \\
\text { (B) = skor posttes-skor pretes }
\end{gathered}
$$

\begin{tabular}{|c|c|}
\hline $\mathrm{G}$ & Keterangan \\
\hline $\mathrm{g}>0,7$ & Tinggi \\
\hline $\begin{array}{c}0,3<\mathrm{g} \\
\leq 0,7\end{array}$ & Sedang \\
\hline $\mathrm{g} \leq 0,3$ & Rendah \\
\hline
\end{tabular}

Teknik analisis data menggunakan rumus indeks Gain untuk analisis kuantitatif, dan analisis konsep pembelajaran dan pendidikan karakter untuk analisis kualitatif. Indeks Gain digunakan untuk mengukur peningkatan hasil belajar mahasiswa setelah menerapkan strategi practice rehearsal pairs.

Analisis data kuantitatif dilakukan dengan mengumpulkan data pretest dan postest untuk kemudian dihitung menggunakan rumus indeks Gain. Analisis data kualitatif dilakukan melalui Empat tahapan yaitu pengumpulan data, reduksi data, penyajian data dan penarikan kesimpulan dengan menggunakan komponen analisis data model interaktif sebagai model analisis data kualitatif (Miles dan Huberman dalam Rohidi, 2011).

\section{HASIL DAN PEMBAHASAN}

\section{Perkuliahan Seni Tari dan Drama di Prodi PGSD UPGRIS}

Mata kuliah pendidikan seni tari dan drama merupakan salah satu mata kuliah wajib yang ada di Program Studi Pendidikan Guru Sekolah Dasar, Fakultas Ilmu Pendidikan, Universitas PGRI Semarang. Mata kuliah pendidikan seni tari dan drama diberikan di semester 4. Bertujuan agar mahasiswa PGSD UPGRIS sebagai calon guru sekolah dasar memahami teori dan konsep yang berhubungan dengan seni tari dan drama, dan diharapkan mampu dengan terampil menciptakan dan menyajikan tarian untuk anakanak sekolah dasar, serta mampu mengajarkan kembali pada peserta didiknya sesuai dengan tujuan pendidikan (Rencana Perkuliahan Semester Seni Tari dan Drama, 2018).

Materi pada perkuliahan seni tari dan drama dibagi menjadi 2 yaitu materi teori dan praktik. Materi teori meliputi konsep dasar tari dan drama, sedangkan materi praktik meliputi apresiasi tari daerah Jawa Tengah, apresiasi tari nusantara, dan penciptaan drama tari. Tari
Dolalak dari Kabupaten Purworejo sebagai materi daerah Jawa Tengah, sedangkan untuk materi tari nusantara menggunakan tari Sirih Kuning dari Betawi.

Pembelajaran seni tari dan drama pada prodi PGSD UPGRIS lebih banyak diisi dengan materi praktik, oleh karena itu mahasiswa juga dituntut untuk mampu dan terampil dalam membawakan materi tari yang diajarkan. Tentunya kadar penilaian mampu dan terampil menari pada mahasiswa prodi PGSD berbeda dengan penilaian pada mahasiswa prodi seni tari. Beberapa komponen pembelajaran seperti materi, strategi, media, dan evaluasi (Sanjaya, 2009), disusun dengan mempertimbangkan latar belakang prodi PGSD.

Seni memiliki peran dalam pengembangan keterampilan, karakter dan multikecerdasan yang dimiliki oleh peserta didik (Tandi dan Dewi, 2012). Maka sesuai dengan tujuan pendidikan seni pada ranah formal, tari dan drama digunakan sebagai media pendidikan agar mahasiswa mendapatkan pengalaman estetik berupa pengalaman apresiasi dan kreasi seni. Fokus utamanya adalah pengembangan karakter melalui seni. Peningkatan kemampuan pemahaman seni dan keterampilan seni merupakan efek ikutan dari perkuliahan tari dan drama di prodi PGSD UPGRIS.

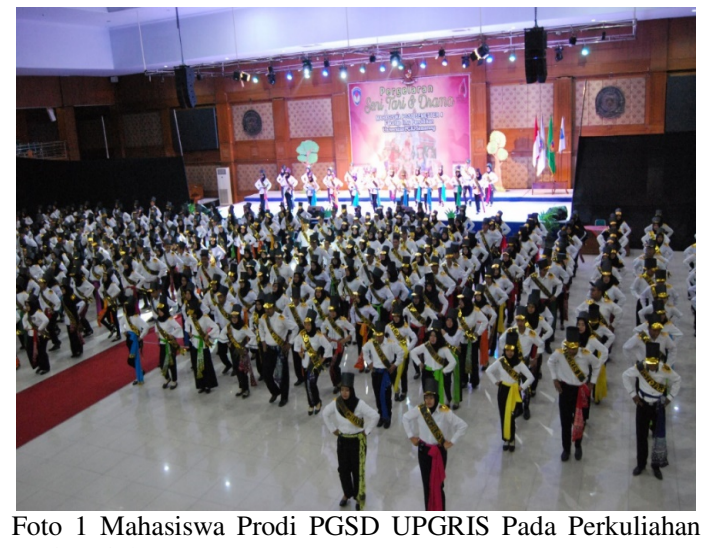
Seni Tari dan Drama

Perkuliahan pendidikan seni tari dan drama di prodi PGSD UPGRIS tahun 2018 diikuti oleh 467 mahasiswa semester 4. Terbagi dalam 11 kelas yaitu A-K. Tidak semua mahasiswa bisa menari, beberapa mahasiswa pernah punya pengalaman menari dan belajar di sanggar tari, dan banyak yang belum pernah menari. Mahasiswa yang dianggap mempunyai kemampuan dalam hal tari, dijadikan koordinator 
kelas untuk mata kuliah seni tari dan drama. Secara kebetulan beberapa mahasiswa yang bisa menari juga mengikuti unit kegiatan mahasiswa seni di UPGRIS.

Metode pembelajaran yang digunakan pada perkuliahan seni tari dan drama di prodi PGSD UPGRIS antara lain metode ceramah, meniru, demonstrasi, drill, penugasan, dan practice rehearsal pairs. Masing-masing metode digunakan secara bergantian menyesuaikan dengan materi yang diberikan. Beberapa metode pembelajaran digunakan agar perkuliahan menjadi lebih menarik, materi menjadi lebih cepat tersampaikan, dan meningkatkan hasil belajar baik secara kognitif, afektif, dan psikomotorik.

\section{Strategi Practice Rehearsal Pairs Pada \\ Perkuliahan Seni Tari dan Drama}

Salah satu strategi yang digunakan pada saat mempelajari tari adalah strategi practice rehearsal pairs. Strategi practice rehearsal pairs merupakan strategi dalam pembelajaran aktif yang digunakan untuk mempraktekkan suatu ketrampilan atau prosedur dengan teman belajar dengan latihan praktek berulang-ulang menggunakan informasi untuk mempelajarinya (Zaini, 2016). Pada strategi ini dua orang mahasiswa akan berpasangan dan saling memberi masukan dalam proses latihan mandiri. Melalui strategi ini diharapkan mahasiswa menjadi lebih aktif dan timbul kebiasaan untuk belajar mandiri di luar jam perkuliahan.

Strategi practice rehearsal pairs dipilih dengan mempertimbangkan aspek mahasiswa, tujuan, proses dan materi perkuliahan yang diberikan, karena strategi practice rehearsal pairs lebih mendukung digunakan pada materi yang bersifat psikomotorik (Pratiwi, 2016). Strategi practice rehearasal pairs diharapkan dapat menjadi inovasi pada pembelajaran seni tari dan drama, menjadikan pembelajaran lebih menarik, mengembangkan karakter mahasiswa, dan dapat menjadi inspirasi bagi dosen untuk mengembangkan materi perkuliahan seni tari dan drama.

Penerapan strategi practice rehearsal pairs dilakukan diantara waktu pemberian materi gerak. Dosen tidak memberikan materi sebanyak-banyaknya dalam satu pertemuan, tetapi dibagi dalam 3 pertemuan. Pada pertemuan pertama diberikan materi gerak 1-3. Pertemuan kedua materi gerak 4-6. Pertemuan ketiga materi gerak 7-9. Sebagai contoh pada pertemuan pertama, setelah materi gerak 1-3 sudah diberikan kemudian mahasiswa diberikan kesempatan untuk berlatih mandiri di kelas dengan didampingi oleh dosen. Dosen memberikan arahan kepada tiap pasangan untuk saling memperhatikan gerak pasangannya dan memberi masukan.

Semisal penari A di sebelah kanan dan penari B di sebelah kiri. Awalnya penari A mendemonstrasikan gerakannya, lalu penari B memberi masukan jika ada yang kurang. Setelah itu ditukar penari B mendemonstrasikan gerakannya dan penari A menjadi pengamat untuk memberikan masukan kepada penari B. Setelah penari A dan B telah mendemonstrasikan gerakannya dan mendapat masukan dari pasangannya, selanjutnya adalah menukar hafalan atau materi gerak yang telah dipelajari.

Penari A yang berada di kiri dan penari B yang ada di kanan saling bertukar posisi dan bertukar materi gerak. Tujuannya bukan untuk membuat bingung mahasiswa, tetapi untuk memberikan kesempatan pada mahasiswa saling mempraktikan pemahaman yang dimiliki berdasar pengalaman yang terbentuk (Nurrika, 2016). Dengan bertukar posisi, mahasiswa dapat memahami gerak dari pasangannya sehingga memunculkan kesadaran gerak dan rasa dalam tari.

Sebagai contoh penari A yang berada di kiri mempelajari gerak penari B yang ada di kanan, maka penari A akan merasakan gerakan penari B dan secara tidak langsung akan memunculkan sikap dan perasaan pada penari agar gerakan asli pada masing-masing penari dapat sesuai, tepat, dan saling mengisi dengan gerakan pasangannya. Pola pembelajaran semacam ini diulang pada setiap pertemuan sampai materi tarinya selesai.

\section{Hasil Penerapan Strategi Practice Rehearsal Pairs}

Setelah materi tuntas diberikan, kemudian diadakan penilaian sebagai bentuk evaluasi pembelajaran. Penilaian pada penelitian dilakukan 2 kali yaitu sebelum menerapkan strategi practice rehearsal pairs yang digunakan sebagai nilai pretest, dan setelah menerapkan strategi practice rehearsal pairs yang digunakan sebagai nilai postest. Nilai prestest dan postest setiap kelas selanjutnya diolah dengan rumus indeks Gain dan ditampilkan dalam bentuk tabel. Rata-rata hasil perkuliahan dari kelas A-K terlihat pada tabel di bawah ini. 
Prasena Arisyanto, Mei Fita Asri Untari, dan Riris Setyo Sundari

PENERAPAN STRATEGI PRACTICE REHEARSAL PAIRS PADA KULIAH SENI TARI DAN DRAMA ... REFLEKSI EDUKATIKA : Jurnal Ilmiah Kependidikan 10 (1) Desember 2019. Hlm. 1-9

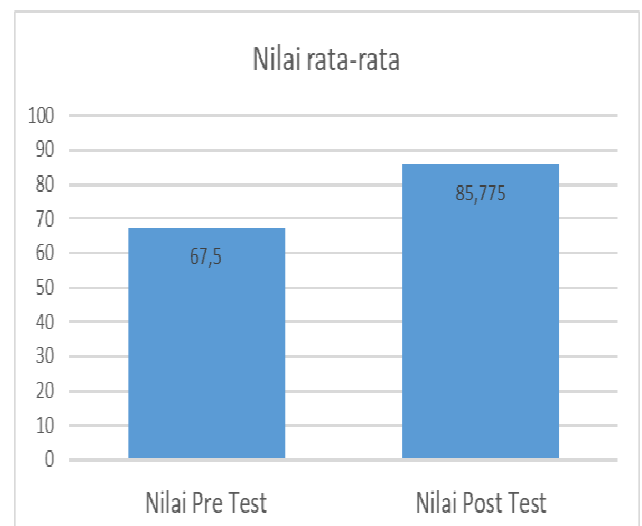

Tabel 1 Nilai Rata-rata Kelas A-K Pada Penerapan Strategi Practice Rehearsal Pairs.

Hasil penelitian menunjukan bahwa ada peningkatan hasil belajar mahasiswa setelah menerapkan strategi practice rehearsal pairs. Nilai rata-rata pretest dari 11 kelas adalah 67, 5, setelah diterapkan strategi practice rehearsal pairs nilai rata-rata 11 kelas naik menjadi 85 , 775. Peningkatan yang diukur dengan indeks Gain didapatkan hasil $\mathrm{g}=1,04$, atau $\mathrm{g}>0,7$ yang termasuk dalam kategori tinggi. Nilai terendah pretest adalah 50, nilai tertinggi pretest adalah 78. Setelah diterapkan strategi practice rehearsal pairs didapatkan nilai terendah postest 75 , dan nilai tertinggi postest 96 .

Indikator penilaian yaitu hafalan gerak, kesesuaian dengan musik, dan interaksi antar penari. Teknik tari tidak menjadi indikator dalam penilaian karena tujuan mata kuliah pendidikan seni tari dan drama di prodi PGSD berbeda dengan di prodi pendidikan sendratasik.

Penelitian Noviana (2013), mendeskripsikan penerapan strategi practice rehearsal pairs pada pembelajaran seni tari di SMP. Penerapan strategi practice rehearsal pairs dapat memberikan dampak positif pada siswa, yaitu siswa merasa lebih nyaman, senang mengikuti pelajaran, dan siswa mampu mengasah kreativitas siswa dengan menemukan motif gerak dalam eksplorasi gerak yang dilakukan.

Peningkatan hasil belajar melalui penerapan strategi practice rehearsal pairs juga dibuktikan pada penelitian Pratiwi (2016), dan Nurrika (2016). Pada penelitian Pratiwi terjadi peningkatan hasil belajar setelah penerapan strategi practice rehearsal pairs. Hasil pretest didapatkan 7 siswa (22\%) termasuk kategori tinggi (nilai $59 \mathrm{ke}$ atas), 15 siswa (47\%) termasuk kategori sedang (nilai antara $25-59$ ), dan 10 siswa $(31 \%)$ dalam kategori rendah (nilai
25 ke bawah). Sedangkan hasil posttest 11 siswa $(34 \%)$ termasuk kategori tinggi (nilai 99 ke atas), 13 siswa (41\%) termasuk kategori sedang (nilai antara71 - 99), dan 8 siswa (25\%) dalam kategori rendah (nilai 71 ke bawah).

Pada penelitian Nurrika (2016) terjadi peningkatan hasil belajar kognitif yang ditunjukkan dengan $\mathrm{N}$-Gain kelas eksperimen sebesar 0,74 dalam kategori tinggi atau lebih besar dibandingkan N-Gain kelas kontrol sebesar 0,62 dalam kategori sedang. Selain itu, terdapat peningkatan hasil belajar pada aspek afektif dan psikomotorik yang ditunjukkan dengan adanya perbedaan nilai rata-rata tiap aspek kelas eksperimen yang lebih tinggi dari kelas kontrol. Hal ini menunjukkan bahwa strategi Practice Rehearsal Pairs di kelas eksperimen lebih baik daripada pembelajaran konvensional kelas kontrol dan dapat dijadikan alternatif dalam pembelajaran TIK

\section{Peningkatan Hasil Belajar Mahasiswa Melalui Penerapan Strategi Practice Rehearsal Pairs}

Peningkatan hasil belajar mahasiswa didukung oleh beberapa faktor. Guru atau pengajar berperan sebagai sumber belajar, fasilitator, demonstrator, pembimbing, dan evaluator. Pengajar mencoba untuk menerapkan strategi pembelajaran praktik berpasangan dan memilih materi tari yang sesuai dengan latar belakang mahasiswa. Tari yang dipilih adalah tari Dolalak yang tidak banyak mempunyai perbedaan gerak antar penari, dan musik pengiring yang cenderung mudah untuk dipahami ketukannya. Pengajar juga menerapkan strategi praktik berpasangan untuk membantu mahasiswa dalam belajar.

Pemilihan tari Dolalak sebagai materi perkuliahan juga bertujuan untuk mengenalkan dan mengapresiasi tari kerakyatan daerah Jawa Tengah, karena pada umumnya materi tari yang sering dipakai adalah tari klasik maupun tari kreasi. Selain itu sebagaimana disampaikan Sustiawati dkk (2017: 198), pemanfaatan budaya lokal (localgenius knowledge) mempunyai tujuan agar pengalaman belajar mahasiswa menjadi lebih beragam dan perkuliahan menjadi lebih bermakna.

Mahasiswa juga merupakan faktor keberhasilan penerapan strategi praktik berpasangan. Persebaran mahasiswa yang dianggap mempunyai kemampuan lebih dalam bidang tari di setiap kelas cukup merata. Setidaknya dalam setiap kelas ada 1 mahasiswa 
yang dianggap mempunyai kemampuan lebih dalam hal tari dan dapat menjadi sumber belajar kedua ketika mahasiswa yang lain ada yang lupa atau belum paham. Tutor sebaya antar mahasiswa juga berpengaruh terhadap pemahaman mahasiswa dalam menerima materi perkuliahan.

Lingkungan di UPGRIS juga cukup mendukung dalam proses perkuliahan seni tari dan drama. Perijinan yang cukup mudah dalam menggunakan ruang dan waktu untuk latihan, sarana yang cukup memadai, serta lingkungan masyarakat yang tenang juga mendukung dalam proses pembelajaran. Jika proses latihan dilakukan malam hari dapat berjalan dengan lancar karena masyarakat sudah paham mengenai kegiatan malam di kampus dan memberikan batas waktu jam malam yang cukup lama agar mahasiswa bisa berkegiatan di malam hari dengan lebih lancar.

\section{Penguatan Karakter Melalui Perkuliahan Seni Tari dan Drama}

Proses latihan tari diharapkan dapat mengasah karakter gigih, disiplin, dan mandiri pada diri mahasiswa. Kesulitan yang dihadapi ketika memahami dan melakukan gerak tari, kemudian memadukan dengan musik, dan akhirnya mampu membawakan tari sesuai dengan gerak dan iringan merupakan usaha yang tidak mudah sehingga diperlukan sikap pantang menyerah dan gigh untuk terus belajar sampai apa yang dipelajari dipahami betul dan mampu dikuasai dengan baik.

Menari memerlukan kedisiplinan yang tinggi. Jika tidak mampu menghafal gerak, kemudian tidak mampu menyesuaikan dengan ketukan musik, maka tari akan menjadi kacau dan jelek sehingga mahasiswa benar-benar harus disiplin dan mengikuti secara ketat ketukan iringan musik yang ada dalam sebuah tarian. Terlambat atau lebih cepat sedikit saja dalam membawakan gerakan tari tentu akan berpengaruh pada penampilan dan penghayatan sebuah tari. Oleh karena itu harus benar-benar paham gerakan, musik, dan mampu membawakan gerakan secara tepat sesuai dengan iringan musik.

Dosen pada perkuliahan seni tari dan drama hanya sebatas sebagai demonstrator, motivator, dan penjelas. Mampu atau tidaknya mahasiswa dalam membawakan sebuah tarian tergantung pada diri mahasiswa sendiri. Jika sering berlatih maka akan dapat membawakan tarian dengan baik. Kemandirian mahasiswa dalam berproses, latihan, dan belajar merupakan kunci untuk dapat membawakan tarian dengan baik. Kemandirian inilah yang diharapkan dapat muncul dan terbawa pada sisi kehidupan yang lain dalam diri mahasiswa.

Tari berpasangan mempunyai kesulitan dan keunikan tersendiri. Jika dapat dilakukan dengan baik, tari berpasangan akan menjadi lebih indah dan menarik. Untuk dapat membawakan tari berpasangan dengan baik maka diperlukan latihan bersama dan sikap saling mengerti antar penari. Jika salah satu penari belum paham, maka rekannya harus dengan sabar menjelaskan sampai kedua penari tersebut dapat membawakan gerakan tari dengan baik. Proses latihan dapat mempererat persahabatan antar individu (Noviana, 2013), dan melatih kepekaan dalam memahami orang lain. Selain itu pada proses latihan tari berpasangan dapat memunculkan karakter peduli, tanggung jawab, komunikatif, dan demokratis.

Antar penari dalam satu pasangan harus saling mempunyai kepedulian. Jika salah satu penari belum paham atau belum bisa melakukan gerak tari dengan benar, maka kewajiban rekannya harus memberi penjelasan dan dengan sabar berlatih bersama. Jika tidak mempunyai kepedulian dengan rekan maka tidak akan bisa membawakan tarian dengan baik. Sikap peduli inilah yang diharapkan dapat menjadi karakter dalam diri mahasiwa agar selalu mempunyai kepedulian terhadap sesama manusia, lingkungan, masyarakat, dan bernegara.

Tari berpasangan dapat baik dan indah jika dapat dibawakan dengan baik oleh 2 orang penari dalam satu pasangan. Oleh karena itu baik atau tidaknya pembawaan tari berpasangan merupakan tanggung jawab semua penari dalam pasangan tersebut. Tidak mungkin bisa jika hanya 1 penari yang mampu menari dengan baik lalu tariannya akan menjadi baik. Diperlukan kerjasama dan tanggung jawab bersama dalam membawakan tari berpasangan.

Proses latihan tari berpasangan merupakan proses komunikasi antar penari, sehingga jika ingin baik dalam membawakan tari berpasangan, komunikasi yang baik harus pula terbangun antar penari. Ketika latihan akan terjadi eksplorasi antar penari. Eksplorasi yang dilakukan bukan untuk mencari gerak baru, tetapi untuk menyelaraskan gerak dan musik maupun untuk melatih kepekaan antar penari (Desfiarni, 2009).

Komunikasi bukan hanya secara lisan ketika proses latihan. Tetapi ketika menari, komunikasi 
Prasena Arisyanto, Mei Fita Asri Untari, dan Riris Setyo Sundari

PENERAPAN STRATEGI PRACTICE REHEARSAL PAIRS PADA KULIAH SENI TARI DAN DRAMA ... REFLEKSI EDUKATIKA : Jurnal Ilmiah Kependidikan 10 (1) Desember 2019. Hlm. 1-9

dapat berlangsung secara visual maupun perasaan tanpa harus berkata-kata. Melihat pola gerak pasangan dan berusaha menyesuaikan dengan paangan merupakan bentuk komunikasi non verbal yang pasti dan selalu terjadi ketika sedang menari. Komunikasi non verbal dalam tari inilah yang dapat memunculkan perasaan tenggang rasa, saling mengerti, saling menghormati dengan orang lain.

Beberapa nilai karakter yang diharapkan muncul, berkembang, dan merasuk dalam diri setiap mahasiswa melalui pembelajaran tari, bukan hanya diharapkan berlangsung selama proses perkuliahan seni tari dan drama. Tetapi, berbagai karakter yang muncul dan dipelajari mahasiswa dapat mengendap dalam setiap jiwa mahasiswa yang kemudian akan terus berlaku, bermanfaat dalam berbagai aktivitas kehidupan mahasiswa. Lebih jauh lagi, diharapkan karakter mahasiswa dapat berkembang dan bermanfaat dalam pengembangan diri baik ketika di lingkungan universitas, di lingkungan kerja, dan di lingkungan masyarakat. Penanaman dan penguatan karakter mahasiswa inilah yang merupakan inti dari pembelajaran seni tari dan drama di Universitas PGRI Semarang.

Pendidikan karakter senantiasa melibatkan aspek pengetahuan, perasaan, dan tindakan (Lickona dalam Sutjipto, 2010). Pembelajaran tari sangat sesuai dengan proses Pendidikan karakter. Mahasiswa harus memahami dan hafal terlebih dahulu materi tari yang dipelajari. Selanjutnya dalam proses latihan berpasangan, setiap individu harus saling berkomunikasi, saling memperhatikan agar bisa membawakan tari secara berpasangan dengan baik. Proses latihan tari merupakan tindakan yang mengasah perasaan dan kepekaan setiap mahasiswa.

Pembelajaran seni tari dan drama dapat difungsikan sebagai media pendidikan jasmani dan rohani. Media pendidikan jasmani terkait dengan aktivitas tari yang menuntut penari untuk bergerak, dan dapat melakukan berbagai gerakan pada berbagai anggota tubuh. Pendidikan jasmani melalui tari dapat dilakukan pada latihan olah tubuh yaitu latihan mempersiapkan otot tubuh agar lentur dan dapat melakukan berbagai macam gerakan. Proses ketika menari juga merupakan aktivitas fisik yang berfungsi mengembangkan ketrampilan, ekspresi fisik, dan memfungsikan organ (Jazuli, 2016).

Fungsi mengembangkan keterampilan merupakan hal dasar dalam pembelajaran tari. Latihan menari merupakan latihan untuk mengembangkan kemampuan psikomotorik dan keterampilan mahasiswa dalam bergerak. Jika mahasiswa mampu melakukan gerak tari dengan baik dan benar maka dapat disebut telah terampil dalam menari. Keterampilan didapatkan melalui proses latihan dan praktik yang terus menerus dan rutin. Tidak ada keterampilan yang cukup dipelajari dengan membaca buku. Keterampilan harus dilakukan dan terus dicoba dengan praktik sampai bisa dan menguasai apa yang dipelajari.

Pembelajaran tari juga membutuhkan ekspresi fisik. Tubuh merupakan media gerak tari untuk mengungkapkan isi atau pesan dalam sebuah tarian. Untuk itu selain ketrampilan atau kemampuan tubuh dalam melakukan gerak tari, tubuh juga mampu untuk berekspresi untuk memperkuat pengungkapan isi tari. Salah satu contoh ekspresi fisik yang mudah dilihat, dikenali, dan dipahami oleh masyarakat adalah ekspresi pada wajah atau mimik muka. Ekspresi muka paling mudah untuk dikenali dan dilakukan untuk mengungkapkan isi atau perasaan yang ingin disampaikan.

Tari juga mempunyai fungsi pada pendidikan rohani penarinya. Nilai tari dalam perkembangan rohani diantaranya tari memerlukan disiplin yang tinggi. Telah dijelaskan sebelumnya bahwa jika gerak tari tidak dilakukan dengan gerak yang tepat dan dalam iringan musik yang sesuai maka akan menjadi kurang indah. Oleh karena itu dalam menari harus benar-benar sesuai dengan gerak tari dan sesuai dengan musik tari. Kedisiplinan dalam membawakan tarian ini yang diharapkan akan melatih sikap disiplin dalam kehidupan mahasiswa sehari-hari. Misalnya displin untuk kuliah, mengerjakan tugas, beribadah, termasuk displin dalam membagi waktu untuk mengatur pola hidup.

Tari membutuhkan ekspresi pribadi, yaitu untuk menambah nilai keindahan dalam tari maka penari harus dapat mengekspresikan isi tari melalui dirinya sendiri. Penari harus paham bagaimana ekspresi untuk suasana senang, serius, agung, maupun sedih. Kemampuan ekspresi pribadi ini diharapkan dapat memupuk rasa kepedulian mahasiswa dalam kehidupannya. Ketika menghadapi sebuah permasalahan dapat mengerti bagaimana dirinya harus bersikap dan bertindak untuk menyelesaikan masalah atau tugas yang sedang dihadapi.

Nilai tari pada perkembangan rohani yang ketiga adalah tari memberikan keluwesan tubuh dan kontrol yang besar. Salah satu nilai 
keindahan dalam tari adalah jika penari bisa membawakan gerak tari dengan luwes. Luwes dalam hal ini bukanlah suatu sikap gerak yang halus, pelan, feminim. Tetapi luwes adalah kemampuan penari dalam membawakan dan menghayati gerak tari yang sesuai dengan karakter tari (Jazuli, 2008). Misal karakter tari putra gagah, maka seorang penari yang dapat membawakan tari yang memunculkan kesan gagah dapat dikatakan telah luwes dalam menari.

Menari juga butuh kontrol diri yang kuat. Bagaimana penari mengatur tenaga untuk menari, mengatur emosi dalam ekspresi gerak tari, mengatur diri agar sesuai dengan pasangan atau kelompoknya perlu untuk dilatih dan dipahami. Menari bukan hanya urusan gerak dan musik, tetapi kontrol diri dan penghayatan juga merupakan unsur penting dalam tari. Keluwesan tubuh dan kontrol diri pada pembelajaran tari diharapkan dapat menumbukan karakter mahasiswa yang luwes dalam menghadapai segala kondisi atau permasalahan dan mampu menyelesaikan hal yang dihadapi dengan baik. Kemampuan untuk mengontrol diri agar dapat berpikir dengan bijak kemudian bertindak dengan tepat sehingga dapat menyelesaikan masalah, merupakan salah satu tujuan utama dalam pembelajaran seni.

Tari juga dapat membantu perkembangan persepsi. Persepsi berkaitan dengan kemampuan dalam mengekspresikan diri. Ketika mahasiswa melihat sebuah tari atau dramatari kemudian diminta untuk menceritakan ulang tari tersebut maka akan melatih daya tangkap dan persepsinya terhadap tari yang telah dilihat. Kemampuan persepsi ini yang kemudian akan mempengaruhi kreativitas dalam melakukan tindakan. Pada kehidupan sehari-hari, kemampuan mempersepsikan suatu hal akan mempengaruhi pola pikir dan tindakannya untuk menyelesaikan perihal yang menjadi tanggung jawabnya.

Nilai tari dalam perkembangan rohani yang kelima adalah menari dapat mendorong timbulnya rasa seni dan sikap apresiatif terhadap seni. Secara tekstual dengan seringnya menari atau melalui proses berkesenian, maka akan memupuk sikap apresiatif terhadap karya seni. Mahasiswa akan dapat mengapresiasi berbagai macam bentuk seni sebagai ekspresi jiwa manusia dan sebagai kekayaan budaya nusantara. Sehingga tidak ada anggapan bahwa suatu budaya lebih unggul dari budaya yang lain, tetapi perbedaan seni dan budaya di Indonesia adalah suatu kekayaan bangsa, anugrah, dan kekuatan pemersatu bangsa Indonesia.

Secara kontekstual, sikap apresiatif yang muncul melalui proses berkesenian diharapkan dapat mengendap dalam diri mahasiswa menjadi karakater peduli dan saling menghargai. Pengalaman estetik yang dialami oleh mahasiswa dapat berfungsi untuk melatih dan mengembangkan kepekaan rasa terhadap lingkungan sekitar (Sumaryanto, 2016). Diharapkan mahasiswa dapat menerapkan sikap apresiasi dalam kehidupannya seperti menghargai perbedaan pendapat, perbedaan antar indvidu, dan dapat saling menghormati dalam keanekaragaman.

\section{SIMPULAN}

Perkuliahan seni tari dan drama di Universitas PGRI Semarang bukan bertujuan untuk mendidik mahasiswa menjadi seniman tari atau dapat menguasai teknik tari dengan baik, tetapi lebih pada usaha penguatan pendidikan karakter mahasiswa melalui media tari dan drama. Penguatan pendidikan karakter yang dilakukan diharapkan dapat bermanfaat bagi mahasiswa terutama ketika telah masuk ke dunia kerja dan berkarya di masyarakat.

Keberhasilan penerapan strategi practice rehearsal pairs pada perkuliahan seni tari dan drama bukan hanya keberhasilan dosen sebagai pengajar, tetapi merupakan hasil kerjasama yang baik antar komponen pembelajaran dan lingkungan. Hasil pada penelitian ini bukanlah hasil yang mutlak dan pasti terjadi diberbagai lembaga pendidikan. Namun dapat dijadikan sebagai referensi mengenai penerapan strategi practice rehearsal pairs pada pembelajaran seni tari dan drama. Hasil yang berbeda dapat terjadi jika diterapkan di lembaga lain, oleh pelaku yang berbeda, dan dengan materi yang berbeda. Oleh sebab itu masih terbuka kesempatan bagi peneliti lain untuk melakukan penelitian serupa, agar dapat saling mendukung atau saling mengoreksi penelitian ini.

\section{DAFTAR PUSTAKA}

Arisyanto, P., et al. 2018. Pembelajaran Ekstrakurikuler Tari Untuk Penanaman Karakter Bagi Siswa SDN Gayamsari 02 Semarang. Jurnal Pendidikan dan Kajian Seni, 3 (1): 1-13. 
Prasena Arisyanto, Mei Fita Asri Untari, dan Riris Setyo Sundari

PENERAPAN STRATEGI PRACTICE REHEARSAL PAIRS PADA KULIAH SENI TARI DAN DRAMA ... REFLEKSI EDUKATIKA : Jurnal Ilmiah Kependidikan 10 (1) Desember 2019. Hlm. 1-9

Desfiarni. 2009. Rangsang Awal Sebagai Motivasi dalam Pembelajaran Koreografi di Jurusan Pendidikan Sendratasik. Jurnal Bahasa dan Seni, 10 (2): 75-80.

Jazuli. 2008. Paradigma Kontekstual Pendidikan Seni. Surabaya: Unesa University Press.

Jazuli. 2016. Peta Dunia Seni Tari. Sukoharjo: Farishma Indonesia.

Nurrika, A, Sutarno, I Made S. 2016. Strategi Pembelajaran Practice Rehearsal Pairs dalam Meningkatkan Hasil Belajar Siswa Pada Mata Pelajaran TIK Kelas VIII di SMPN 2 Ungaran. Jurnal Edu Komputika, 3 (1): 68-74.

Noviana, D.Y., Frahma S., Sri D.M. 2013. Pelaksanaan Pembelajaran Seni Tari dengan Strategi Practice Rehearsal Pairs Pada Siswa Kelas VII di SMPN 49 Bandung. Jurnal Ringkang, 1 (3): 1-15.

Pratiwi, A.C, dan Tutut H. 2016. Penerapan Strategi Practice Rehearsal Pairs (Praktik Berpasangan) Terhadap Hasil Belajar Siswa Kelas II Pada Mata Pelajaran Fiqih di Madrasah Ibtidaiyah Darul Aitam Palembang. Jurnal Ilmiah PGMI, 2 (1): 83-94.

Rohidi, T.R. 2011. Metodologi Penelitian Seni. Semarang: Cipta Prima Nusantara.

Sanjaya, W. 2009. Strategi Pembelajaran Berorientasi Standar Proses Pendidikan. Jakarta: Kencana.
Sugiyono. 2011. Metode Penelitian Kombinasi (Mix Methods). Bandung: Alfabeta.

Sumaryanto, F.T. 2016. Pembelajaran Musik Tradisional Sebagai Ruang Komunikasi Budaya dan Pembentukan Karakter Peserta Didik. Prosiding Seminar Nasional Seni Pertunjukan dan Pendidikan Seni FBS UNNES 2016, 5162.

Sustiawati, N.L. et al. 2017. Pengembangan Desain Pembelajaran Seni Tari di Sekolah Dasar Berbasis "Localgenius Knowledge" Berpendekatan "Integrated Learning". Jurnal Seni Budaya Mudra, 32 (1): 197208.

Sutjipto. 2011. Rintisan Pengembangan Pendidikan Karakter Di Satuan Pendidikan. Jurnal Pendidikan dan Kebudayaan, 17 (5): 501-524.

Syafii. 2014. Pendidikan Seni: Hakikat, Fungsi, dan Pendekatan Pembelajarannya. Prosiding Seminar Nasional Pengembangan Sumber Daya Manusia Melalui Seni Dan Pendidikan Seni FBS UNNES 2014, 121-129.

Tandi, H.Y dan Andi I.D. 2012. Pengembangan Pembelajaran Seni Tari Dan Drama Pada Program Studi PGSD, FKIP, Universitas Tadulako. Jurnal Dikdas, 1 (1): 1-17.

Zaini, H. Bermawy M. Sekar A.A. 2016. Strategi Pembelajaran Aktif. Yogyakarta: CTSD. 